\title{
Hereditary Heinz-body Anaemia, Thrombocytopenia, and Haemoglobinopathy (Hb Köln) in a Glasgow Family
}

\author{
H. E. HUTCHISON,* M.D., M.R.C.P.G. ; P. H. PINKERTON,* M.B., M.R.C.P.ED. ; \\ PATRICIA WATERS,* B.SC. ; A. S. DOUGLAS, $\dagger$ M.D., F.R.C.P., F.R.C.P.ED. ; \\ H. LEHMANN, $\ddagger$ M.D., SC.D., F.R.C.P., F.R.I.C., F.C.PATH. ; D. BEALE, $\ddagger$ B.SC.
}

Brit. med. F., 1964, 2, 1099-1103

Exposure to certain drugs may result in haemolytic anaemia and the appearance of inclusions (Heinz bodies) in the red cells. This may occur from simple drug overdosage-for example, with phenacetin-in the absence of any known abnormality of the red cells (Hutchison, Jackson, and Cassidy, 1962) ; or, in the absence of drug overdosage, the occurrence may be determined by an intrinsic abnormality of the cells, usually familial, such as lack of the enzyme glucose-6-phosphate dehydrogenase (Beutler, 1959); this has been known for some time. More recently it has been shown that a similar effect of drugs may be associated with the presence of an abnormal haemoglobin fraction (Frick, Hitzig, and Betke, 1962). It now becomes clear (Scott, Haut, Cartwright, and Wintrobe, 1960 ; Shibata, Iuchi, Miyaji, Ueda, Takeda, 1963 ; Grimes, Meisler, and Dacie, 1964 ; Dacie, Grimes, Meisler, Steingold, Hemsted, Beaven, and White, 1964) that, in the absence of any drug exposure, haemolytic anaemia with the appearance of numerous Heinz bodies after splenectomy may be met with in association with the presence of an abnormal haemoglobin fraction. This constitutes one form of familial Heinz-body anaemia, and we wish to present details of 10 members of a family in which the presence of Haemoglobin Köln (Pribilla, 1962) seems to have determined the occurrence of haemolytic anaemia, with thrombocytopenia, and the appearance of Heinz bodies in the red cells following splenectomy.

\section{Methods}

Standard haematological investigations were carried out by the methods of Dacie and Lewis (1963) ; Haemoglobin F was estimated by the modification, by Went and MacIver (1961), of the method of Singer, Chernoff, and Singer (1951); and red-cell survival was assessed by radioactive chromium studies (Mollison and Veall, 1955)-normal $\mathrm{T}_{\frac{2}{2}}{ }^{1} \mathrm{Cr}$ is $20-26$ days. The method used by Doxiadis, Fessas, Valaes, and Mastrokalos (1961) was employed to detect glucose-6-phosphate dehydrogenase activity. We are indebted to Professor T. A. J. Prankerd for estimations of glucose consumption, glucose-6-phosphate dehydrogenase, pyruvate kinase, glutathione reductase, and methaemoglobin reductase. The formation of methaemoglobin in vitro was followed by the method of Bachman (1962), and the presence of a heat-precipitable haemoglobin fraction was sought as described by Dacie et al. (1964).

Preliminary electrophoresis of the haemoglobin in starch gel and estimation of the abnormal fraction by scanning the gel slices was as described by Hutchison, Pinkerton, Aiton, and Cassidy (1963). The abnormal haemoglobin could also be demonstrated by paper electrophoresis, using TRIS buffer pH 8.9 (Cradock-Watson, Fenton, and Lehmann, 1959). On starch-gel electrophoresis with Poulik's (1957) discontinuous TRIS-borate technique the abnormal fraction migrated behind Haemoglobin A, and overlapping with the position of Haemo-

* University Department of Haematology, Western Infirmary, Glasgow. University Department of Medicine, Royal Infirmary, Glasgow. ¥M.R.C. Abnormal Haemoglobin Research Unit, University Department of Biochemistry, Cambridge. globin $\mathrm{F}$ in front of Haemoglobin S. Good separation was also obtained on agar-gel electrophoresis $\mathrm{pH} 6$ according to Robinson, Robson, Harrison and Zuelzer (1957). Hybridization was performed with canine haemoglobin, using the micro-technique of Huehns, Shooter, and Beaven (1962). The haemoglobin was isolated by eluting it after paper electrophoresis, concentrating it in vacuo, and re-electrophoresing twice to remove all traces of $\mathrm{Hb} \mathrm{A}$. "Fingerprints " were prepared according to Ingram (1958) and Baglioni (1961).

\section{Case 1}

The 24-year-old propositus, C. R., a housewife and four months pregnant, had been under investigation in the Royal Infirmary, Glasgow, for repeated episodes of mild jaundice and anaemia, often provoked by minor infection, and associated with lethargy, pallor, and the passage of dark urine, since the age of 9. Palpable splenomegaly was noted at that time. Her haemoglobin was then $80 \%$ and reticulocytes $6 \%$, and the osmotic fragility of the red cells was normal. Her father was known to be similarly affected and underwent splenectomy in 1950. She was therefore regarded as suffering from a form of hereditary non-spherocytic haemolytic anaemia.

During the present admission the tip of the spleen could be palpated $5 \mathrm{~cm}$. below the costal margin. Otherwise no abnormality was noted on clinical examination. No history of drug ingestion was elicited. Examination of the blood showed: $\mathrm{Hb} 92 \%(100 \%=$ 14.6 g.) ; P.C.V. $45 \%$; M.C.H.C. $29.75 \%$; reticulocytes $7 \%$; white-cell count $5,000 /$ c.mm.; platelets $75,000 /$ c.mm.; median corpuscular fragility (M.C.F.) $0.46 \%$; Hb F less than $1 \%$; glucose6-phosphate dehydrogenase activity present ; autohaemolysis without glucose at 48 hours $3.7 \%$, with glucose at 48 hours $2.2 \%$ (narmal $0.4 \%-4.5 \%$ and $0.3 \%-0.4 \%$ respectively); sickling not demanstrable ; serum iron $110 \mu \mathrm{g} . / 100 \mathrm{ml}$. ; serum bilirubin $1.8 \mathrm{mg} . / 100$ $\mathrm{ml}$. $\mathrm{T}_{\frac{1}{2}}^{51} \mathrm{Cr} 9 \frac{1}{2}$ days ; spleen:liver uptake ratio $3: 1$; Coombs's test and Ham's test negative; lupus erythematosus phenomenon not demonstrated. The blood film (Fig. 1) showed only mild

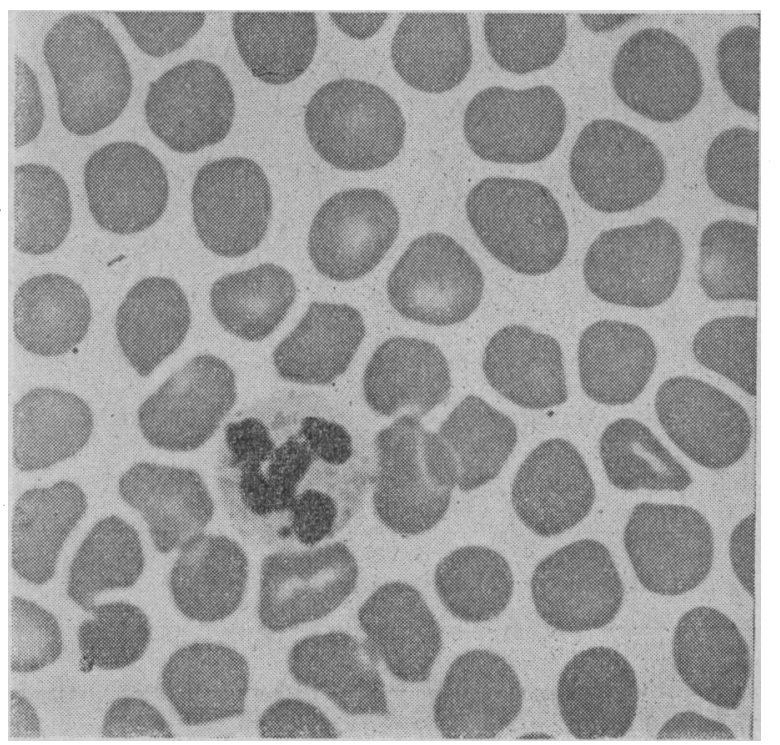

Fig. 1.-Blood film of C.R. before splenectomy. (Leishman. $\times 1,125$. ) 
anisopoikilocytosis and slight microcytosis; neither target cells nor irregularly contracted cells were a feature, and inclusion bodies were not found in Romanowsky-stained films. Examination of the bonemarrow revealed hyperplastic normoblastic erythropoiesis with no other remarkable feature.

The abnormal haemoglobin amounted to about $10 \%$ of the total (Fig. 2), and its presence could also be shown on paper electrophoresis (Fig. 3).

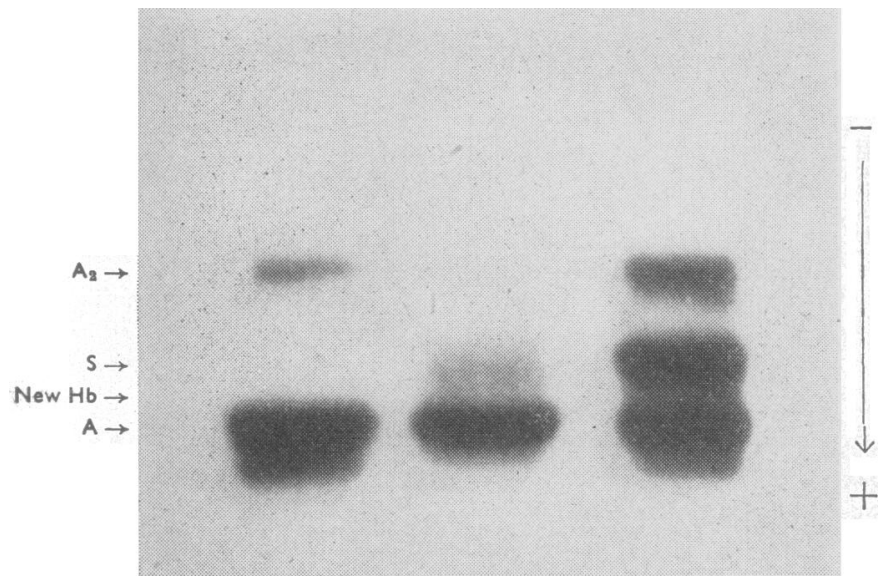

Fic. 2.-Starch-gel electrophoresis (Poulik, 1957). Left, Hb A and A Middle, $\mathrm{HbA}$, the abnormal haemoglobin, and $\mathrm{Hb} \mathrm{A_{2 }}$ (just visible). Right, $\mathrm{Hb} \mathrm{A}, \mathrm{S}$, and $\mathrm{A}_{2}$.

Enzyme studies gave the following results: glucose consumption $2.5 \mu \mathrm{mol} / \mathrm{ml}$. cells/hour; glucose-6-phosphate dehydrogenase 3.25 units $/ \mathrm{ml}$. cells/minute; pyruvate kinase $0.9 \mathrm{unit} / \mathrm{ml}$. cells/minute; glutathione reductase $0.75 \mathrm{unit} / \mathrm{ml}$. cells/minute; methaemoglobin reductase 0.002 units/minute. These rather elevated values are thought to be due to the presence of a young erythrocyte population.

In vitro production of methaemoglobin was increased, the concentration after 18 hours' incubation being $17.3 \%$ of the total haemoglobin present (normal range $0-2.4 \%$ ). The heat precipitability of a haemolysate from the patient was determined (Dacie et al., 1964) in parallel with normal controls. Precipitation occurred between 60 and 120 minutes, whereas the controls remained clear at 150 minutes (Table I). The urine contained no excess of porphyrin, porphyrin precursors, delta-amino laevulic acid, melanin, haemoglobin, or homogentisic acid. Reduction with ferrous sulphate

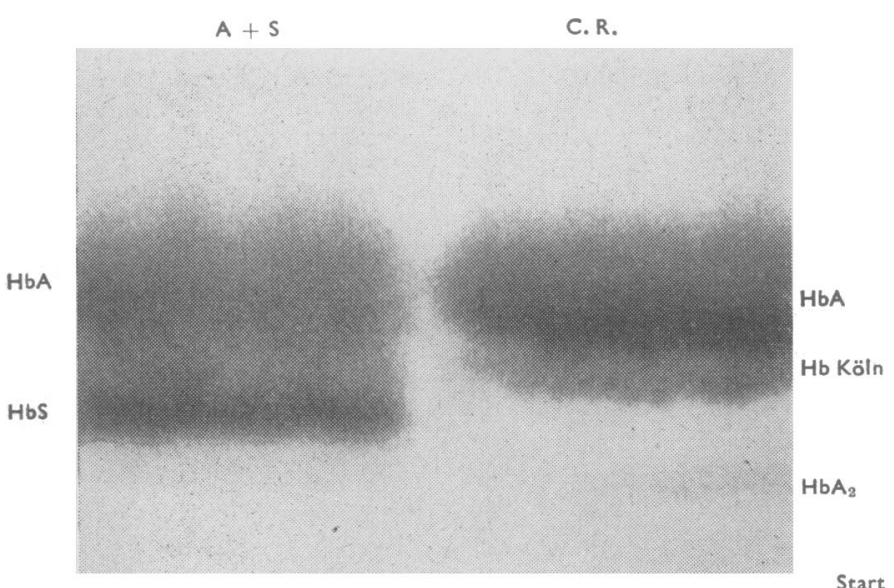

FIG. 3.-Paper electrophoresis of Hb Köln. (TRIS buffer.)

TABLE I.-Heat-precipitability of haemoglobin at $50^{\circ} \mathrm{C}$. in $0.1 \mathrm{M}$ Phosphate Buffer, pH 7.4

\begin{tabular}{|c|c|c|c|c|}
\hline \multirow{2}{*}{ Relationship } & \multirow{2}{*}{ Splenectomy } & \multicolumn{3}{|c|}{ Time (Hours) } \\
\hline & & 1 & 2 & $2\}$ \\
\hline 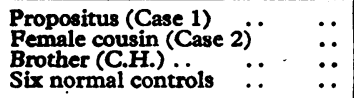 & $\begin{array}{l}\text { Yes } \\
\text { No } \\
\text { No } \\
\text { No }\end{array}$ & $\begin{array}{l}\bar{z} \\
\bar{z}\end{array}$ & $\begin{array}{l}+ \\
+ \\
\pm\end{array}$ & $\begin{array}{l}+ \\
+ \\
\pm \\
-\end{array}$ \\
\hline
\end{tabular}

$+=$ Precipitate present. and sodium amalgam produced no chromogens reactive to dimethylaminobenzaldehyde, showing the absence also of tetrapyrrolic bile pigments. A dipyrrolic pigment fraction with similarities to that of a mesobilifuscin was detected.

\section{Further Progress}

Clinical improvement followed an uneventful splenectomy although the $\mathrm{T}_{2}^{151} \mathrm{Cr}$ improved only to 14 days. After splenectomy the usual Howell-Jolly and Pappenheimer bodies appeared, but in addition large inclusions indistinguishable from Heinz bodies have been constantly present in $75-80 \%$ of red cells, including reticulocytes, in preparations stained supravitally with cresyl blue and methyl violet (Fig. 4). They were not evident in Romanowskystained smears. They appeared to be at least partially soluble in

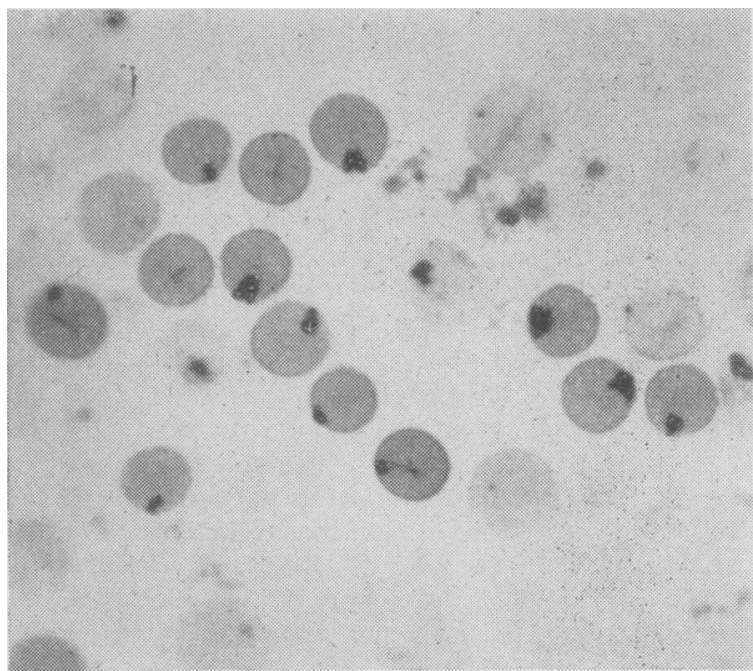

FIG. 4.-Red-cell inclusions, C.R., after splenectomy. (Supravital staining with methyl violet. $\times 750$.)

alcohol, being much reduced in number and size by exposure of a film to ethanol for 30 to 90 minutes. They were - rather poorly defined in phase contrast but easily seen in wet preparations owing to their high refractility. The inclusions failed to stain with the prussian blue, Feulgen, periodic-acid-Schiff, or Unna-Pappenheim methods.

An uneventful birth took place at term. A sample of cord blood, which was not very satisfactory owing to deterioration, was thought to show the presence of the abnormal haemoglobin.

\section{Case 2}

B.H., an affected female cousin of the propositus, a grocer's assistant aged 23, was admitted to the Western Infirmary, Glasgow, for the investigation of the repeated occurrence of spontaneous bruising during the previous four months. The menses were heavier than usual during this time., There was no history of drug consumption and no past history suggestive of jaundice or anaemia. Her urine had been noted to be dark on occasion. Her sister died aged 28 after rupture of an intracranial berry aneurysm. On examination a small bruise was present in the left leg, and the spleen tip was palpable. Icterus was not clinically apparent.

Investigations.- $\mathrm{Hb} 75 \%$; P.C.V. $41.5 \%$; M.C.H.C. $27 \%$ reticulocytes $10 \%$; platelets $70,000 /$ c.mm. ; W.B.C. 5,000/c.mm., with a normal differential count ; Heinz bodies absent ; Coombs's tes and Ham's test negative. The bleeding-time was 21 minutes and Hess's test was weakly positive. No defect was found in the coagulation mechanism, and the leucocyte ascorbic acid was at the lower limit of normal. Serum bilirubin $1.8 \mathrm{mg} . / 100 \mathrm{ml}$; M.C.F. $0.405 \%$ $\mathrm{NaCl}$. ; $\mathrm{T}_{\frac{1}{2}}^{{ }^{51}} \mathrm{Cr} 10$ days ; urinary urobilinogen $10.9 \mathrm{mg} . / 24$ hours ; the spleen:liver ratio 2.5:1. Autohaemolysis at 48 hours without glucose $4.8 \%$, with glucose $2.2 \%$. In samples incubated for 24 and 48 hours several Heinz bodies were present in almost every cell, being more numerous in the aliquots incubated without glucose. Similarly treated normal control samples showed only occasional Heinz bodies after 24 to 48 hours' incubation and these were very scanty where glucose had been added (see Fig. 5). Methaemoglobin 
production was not determined quantitatively, but was of the same order as in C. R. and C. H. Sternal-marrow, examination showed an absence of stainable tron, and normoblastic erythroid hyperplasia. The myeloid series was normal, and although a slight increase in megakaryocytes was present this was not as great as would be expected in idiopathic thrombocytopenic purpura. Electrophoresis of form of hereditary haemolytic anaemia. Osmotic fragility of the red cells following incubation at $37^{\circ} \mathrm{C}$. for 24 hours was decreased in B. H. (Case 2), and also in C.R. (Case 1) and S. H., both of whom had undergone splenectomy when this investigation was performed (see Table III). Such a decrease

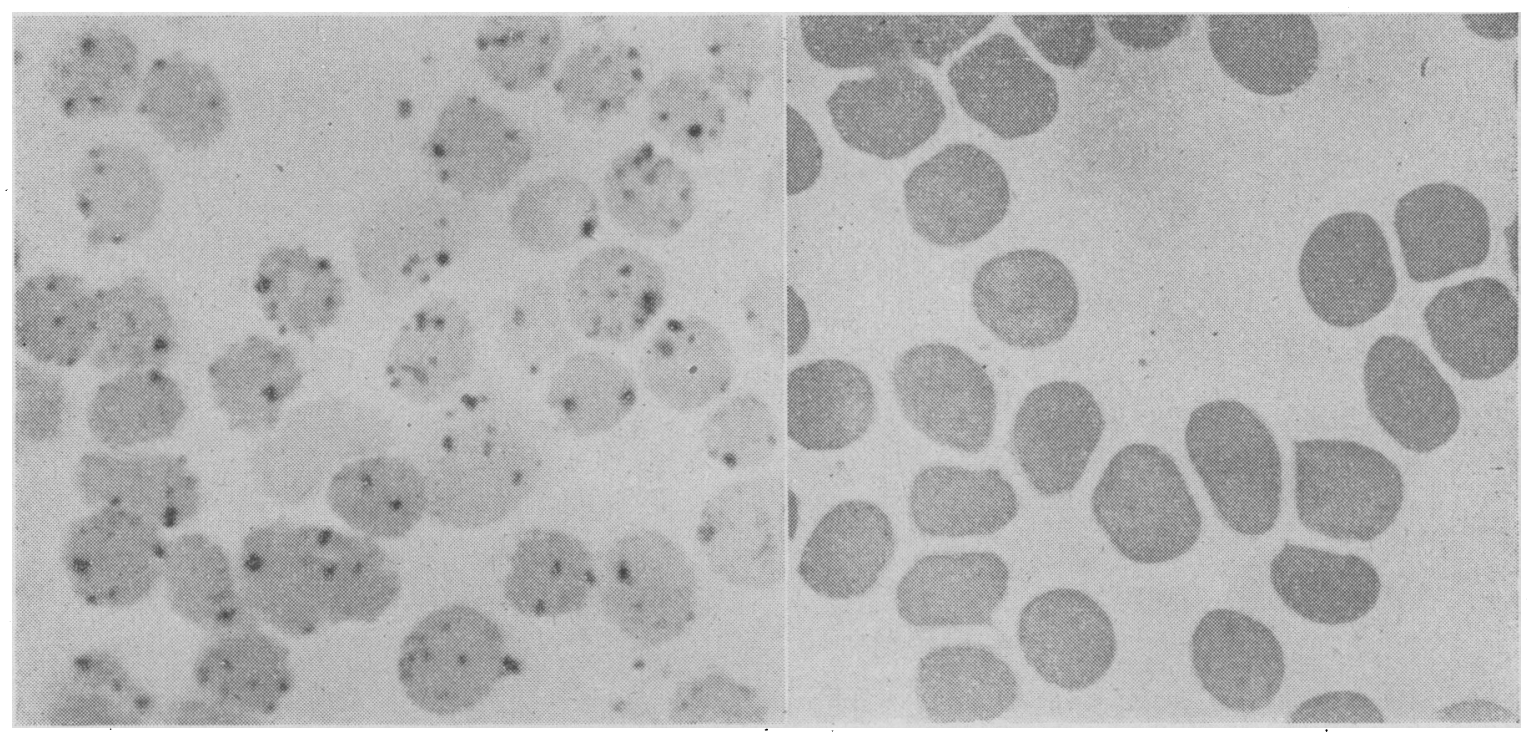

FIG. 5.-Case 2. Left: Red-cell inclusions following incubation. Right: Normal control. $(\times 1,160$.

the haemoglobin in starch gel revealed the same abnormality as was found in Case 1, and the heat-precipitable fraction was also demonstrated (Table I).

\section{Family Studies}

The family tree is presented in Fig. 6. A great-grandfather of the propositus was German.

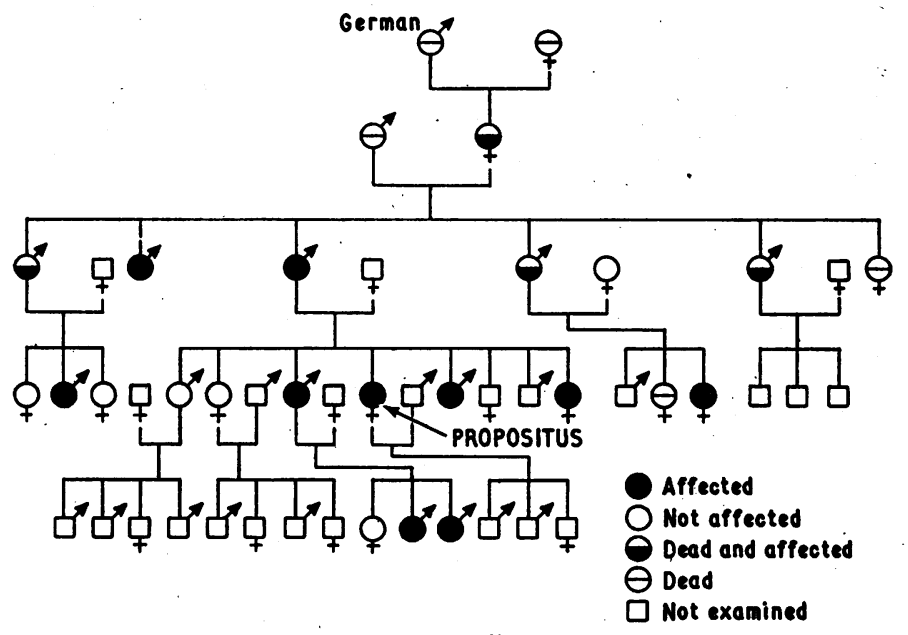

Fig. 6.-Family tree.

Those members of the family designated "dead and affected" are so described on the basis of the history given by surviving relatives. All the affected relatives examined so far give a history similar to that of the propositus, and their blood findings are given in Table II. In general the findings in the affected members are those of a well-compensated, moderately severe haemolytic anaemia, but it will be noted that the M.C.H.C. was consistently reduced and that the majority (7/3) were males, making it seem very unlikely that this would be due to concomitant iron deficiency. The M.C.F. was slightly raised in only one individual. In all others it was either normal or reduced. While the reason for this variability was not clear, it was evident that the family suffered from a non-spherocytic in fragility is sometimes seen in the type I non-spherocytic haemolytic anaemia of Selwyn and Dacie (1954) (Dacie, 1960).

The amount of abnormal haemoglobin present was similar from one subject to another. The four youngest affected showed a distinct increase in the concentration of $\mathrm{Hb} F$;

TABLE II.-Haematological Findings in Affected Members of the Family

\begin{tabular}{|c|c|c|c|c|c|c|c|}
\hline $\begin{array}{l}\text { Initials } \\
\text { and } \\
\text { Sex }\end{array}$ & $\begin{array}{c}\text { Relationship } \\
\text { to } \\
\text { Propositus }\end{array}$ & $\begin{array}{l}\mathrm{Hb} \\
(\%)\end{array}$ & $\underset{(\%)}{\text { M.C.H.C. }}$ & $\begin{array}{c}\text { Retics. } \\
\text { (\%) }\end{array}$ & $\underset{(\%)}{\text { M.C.F. }}$ & $\begin{array}{l}\mathrm{Hb} F \\
(\%)\end{array}$ & $\begin{array}{l}\text { Platelets } \\
\text { /c. mm. }\end{array}$ \\
\hline $\begin{array}{l}\text { S.H. (M) } \\
\text { J.H. (M) } \\
\text { W.H. (M) } \\
\text { C.H. (M) } \\
\text { C.R. (F) }\end{array}$ & $\begin{array}{l}\text { Father after } \\
\text { splenectomy } \\
\text { Uncle } \\
\text { Cousin } \\
\text { Brother } \\
\text { Propositus } \\
\text { before }\end{array}$ & $\begin{array}{l}105 \\
94 \\
94 \\
93 \\
92\end{array}$ & $\begin{array}{l}31 \\
26 \cdot 5 \\
29 \cdot 75 \\
29.25 \\
30\end{array}$ & $\begin{array}{l}4 \\
3 \\
5 \\
7 \\
7\end{array}$ & $\begin{array}{l}0.43 \\
\frac{0.41}{0.46}\end{array}$ & $\begin{array}{l}<1 \\
<1 \\
<1 \\
<1 \\
<1\end{array}$ & $\begin{array}{r}800,000 \\
180,000 \\
120,000 \\
115,000 \\
75,000\end{array}$ \\
\hline $\begin{array}{l}\text { B.H. (F) } \\
\text { T.H. (M) } \\
\text { C.H. (F) } \\
\text { C.H. (M) } \\
\text { D.H. (M) }\end{array}$ & $\begin{array}{l}\text { splenectomy } \\
\text { Cousin } \\
\text { Brother } \\
\text { Sister } \\
\text { Nephew } \\
\text { Nephew }\end{array}$ & \begin{tabular}{|l|}
76 \\
85 \\
76 \\
71 \\
76
\end{tabular} & $\begin{array}{l}27 \cdot 5 \\
29 \cdot 25 \\
29 \\
29 \cdot 75 \\
28 \cdot 5\end{array}$ & $\begin{array}{r}10 \\
6 \\
10 \\
6 \\
6\end{array}$ & $\begin{array}{l}0.405 \\
0.41 \\
0.425 \\
0.36 \\
0.36\end{array}$ & $\begin{array}{l}<1 \\
1.6 \\
1.5 \\
1.7 \\
5.4\end{array}$ & $\begin{array}{r}70,000 \\
100,000 \\
160,000 \\
130,000\end{array}$ \\
\hline
\end{tabular}

TABLE III.-Autohaemolysis and the Effect on the M.C.F. of Incubation of Whole Blood at $37^{\circ} \mathrm{C}$. for 24 Hours

\begin{tabular}{|c|c|c|c|c|c|}
\hline \multirow{2}{*}{ Subject } & & \multicolumn{2}{|c|}{ M.C.F. $\% \mathrm{NaCl}$} & \multicolumn{2}{|c|}{$\begin{array}{l}\text { Autohaemolysis } \\
\text { ( } 37^{\circ} \mathrm{C} \text {. for } 48 \text { hours) }\end{array}$} \\
\hline & & $\begin{array}{c}\text { Before } \\
\text { Incubation }\end{array}$ & $\begin{array}{c}\text { After } \\
\text { Incubation }\end{array}$ & $\begin{array}{l}\text { Without } \\
\text { Glucose }\end{array}$ & $\begin{array}{l}\text { With } \\
\text { Glucose }\end{array}$ \\
\hline $\begin{array}{l}\text { C.R.* (Case 1) } \\
\text { S.H. } \\
\text { B.H. (Cäe 2) }\end{array}$ & $\begin{array}{l}. . \\
. .\end{array}$ & $\begin{array}{l}0.395 \\
0.43 \\
0.405\end{array}$ & $\begin{array}{l}0.34 \\
0.385 \\
0.36\end{array}$ & $\begin{array}{l}3.7 \% \\
4.6 \% \\
4.8 \%\end{array}$ & $\begin{array}{l}2.2 \% \\
3.4 \% \\
2.2 \%\end{array}$ \\
\hline
\end{tabular}

* After splenectomy.

this is regarded as a non-specific increase which may accompany any congenital haemolytic anaemia, although it may be a compensatory increase evoked by a low rate of production of the $\beta$-chain abnormal haemoglobin.

The father of the propositus underwent splenectomy in 1950 without apparent significant clinical benefit, and his blood also shows the presence of inclusion bodies on supravital staining identical to those seen in the propositus after splenectomy. We have not been able to examine a blood film of his made prior to splenectomy.

Inclusion bodies have been sought; however, in Romanowskystained preparations from all non-splenectomized affected mem- 
bers of the family without success. These films show only comparatively minor changes, which are not constant from one individual to another. Furthermore, blood from a brother (C.H.) of the propositus and B.H. (Case 2), neither of whom has had splenectomy, was carefully examined supravitally for the presence of red-cell inclusion bodies, but these have not been found even after four hours' incubation with cresyl blue. However, both show the development of Heinz bodies on incubation of whole blood, and, like the propositus, both exhibit excessive in vitro production of methaemoglobin.

We are unable to assess the biochemical significance of the dipyrrolic type of urinary pigment present in the urine of the propositus and her unsplenectomized brother (C.H.), but presumably it represents a breakdown product of the abnormal haemoglobin fraction.

\section{Nature of the Abnormal Haemoglobin}

As the small fraction found in the affected members of this family resembled in some aspects Haemoglobin Lepore, peptide chromatograms were prepared according to Ingram (1958) and Baglioni (1961) of this haemoglobin, $\mathrm{Hb} \mathrm{A}_{2}$, and $\mathrm{Hb} \mathrm{A}$. $\mathrm{Hb}$ Lepore contains part of the $\delta$-chain (see Huisman, 1963) of $\mathrm{Hb} \mathrm{A}_{2}\left(\alpha_{2} \delta_{2}\right)$. The peptide chromatograms of the present abnormal haemoglobin showed peptides typical of $\mathrm{Hb} \mathrm{A}$, and none of these characteristic of $\mathrm{Hb} \mathrm{A}_{2}$ or of $\mathrm{Hb}$ Lepore. The ultra-violet spectrum and the peptide chromatogram also showed none of the features of $\mathrm{Hb} \mathrm{F}$. Hence we considered the new haemoglobin to be a variant of $\mathrm{Hb} \mathrm{A}$. On several occasions we noted that the $\mathrm{Hb} \mathrm{A}_{2}$ was "split" into two fractions. Both were isolated separately and both gave the identical peptide pattern of $\mathrm{Hb} \mathrm{A}_{2}$ on tryptic digestion followed by electrophoresis and chromatography.

Itano and Robinson's (1959) hybridization with canine haemoglobin (according to Huehns et al., 1962) demonstrated that the abnormality in the haemoglobin under investigation was in the $\beta$-chain (Fig. 7). On prolonged digestion with a trypsin preparation containing traces of chymotrypsin we regularly obtained an additional histidine-containing peptide in the "fingerprint" (Fig. 8). This peptide comes from the

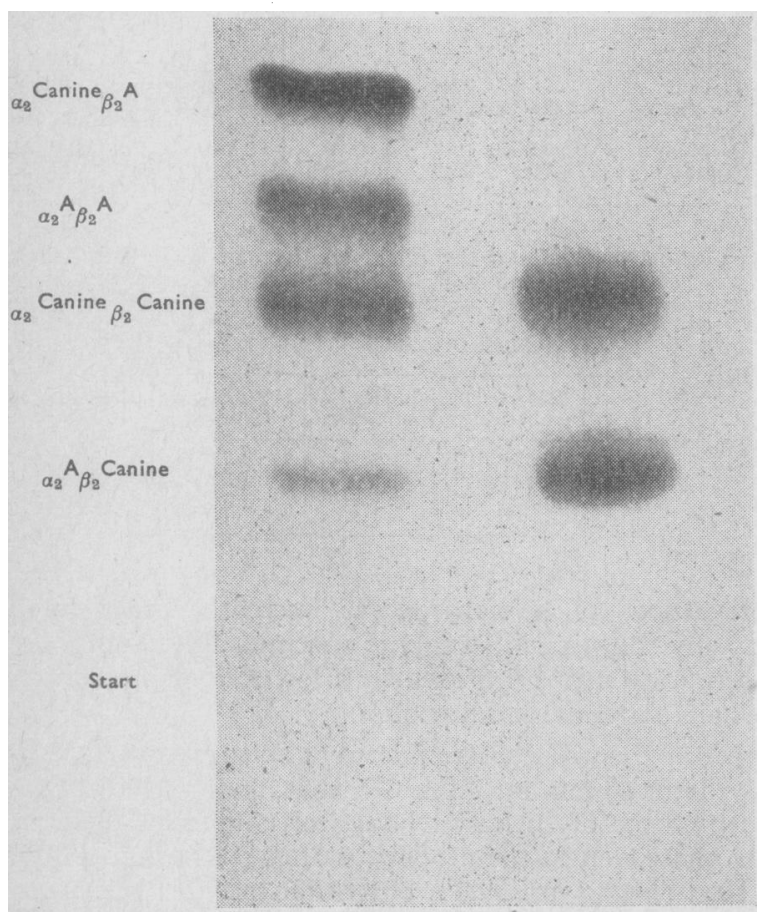

Fig. 7.-Left: Hybridization of human $\mathrm{Hb} A$ with canine $\mathrm{Hb}$. Right: Hybridization of isolated Glasgow Hb with canine Hb. Note that no hybrid corresponding to $\alpha_{2}$ canine $\beta_{2} A$ is formed. $B_{2} A$ is absent and the abnormality in the Glasgow $\mathrm{Hb}$ must rest in the $\beta$-chain. The hybrid $\alpha_{2} \mathrm{~A} \beta_{2}$ canine is present. "core" of the haemoglobin molecule, which is that part which usually remains insoluble after tryptic digestion according to Ingram (1958) and Baglioni (1961). It is therefore possible to place the abnormality as somewhere between residues 83 to 120 of the 146 constituting the $\beta$-chain.

At this time we began to investigate a sample of $\mathrm{Hb}$ Köln kindly sent us by Professor W. Pribilla. Hb Köln turned out to be identical in every respect with the haemoglobin of the Glasgow family, which has German ancestry. The electrophoretic properties were the same, the abnormality could be localized to the $\beta$-chain, and finally the fingerprint showed the same histidine-containing abnormal peptide as the haemoglobin from the Glasgow family. We conclude, therefore, that the haemoglobin described in this paper is Hb Köln.

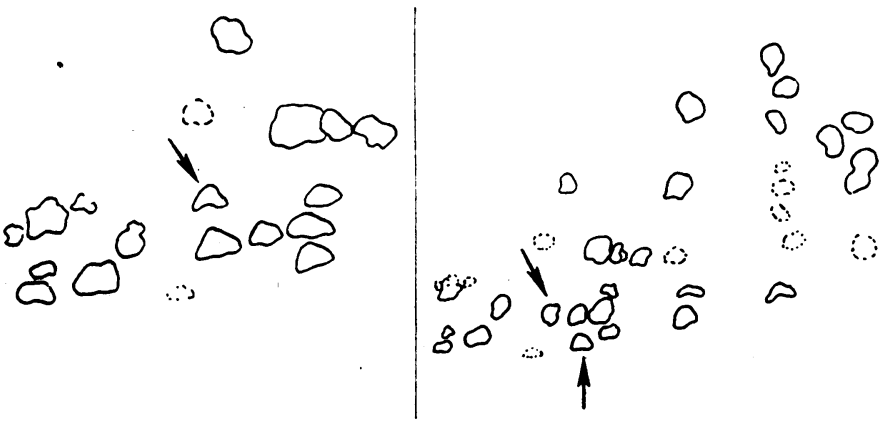

FrG. 8.-Left: Lower left portion of the "fingerprint" of $\mathrm{Hb} \mathrm{A}$; the print " of Hb Köln; the upper arrow indicates the site of the "missing" spot, and the lower arrow the abnormal spot.

\section{Discussion}

Heterozygotes for a specific haemoglobin abnormality seldom present as cases of frank haemolytic anaemia. Indeed, so far, this has been recognized only in the case of Haemoglobin Zurich (Frick et al., 1962), and Haemoglobin $\mathbf{M}_{\text {Chicago }}$ (Josephson, Weinstein, Yakulis, Singer, and Heller, 1962). The Lepore trait is occasionally associated with a mild haemolytic anaemia (Fessas, Stamatoyannopoulos, and Karaklis, 1962 ; Barkan, Stevenson, Pinker, Dance, and Shooter, 1964), and rarely somewhat more severe cases have been seen (Fessas, personal communication). Possibly some alleged instances of $\mathrm{Hb}$ Lepore with really severe haemolytic anaemia have the same form of haemoglobin abnormality present in our family. For example, Pribilla (1962) and Huisman (1963) considered $\mathrm{Hb}$ Köln as a possible $\delta$-chain and possibly a Lepore abnormality.

When a haemoglobinopathy presents in this way it will be classified among the congenital or familial non-spherocytic haemolytic anaemias, and when further characterization is attempted using the autohaemolysis techniques of Selwyn and Dacie (1954) it may be that such cases will, as our family did, fail to fit into either type I or II of that classification. In any event, it is clear from our experience that search for an abnormal haemoglobin is an appropriate investigation in such patients.

Presentation of a heterozygote for an abnormal haemoglobin with thrombocytopenia and a haemorrhagic state (Case 2) is, we believe, unique. The affected members of the family in general (see Table II) showed a tendency to thrombocytopenia, and it seems to have been only a slight exaggeration of this which produced the haemorrhagic symptoms in Case 2. The reason for the thrombocytopenia is not clear. The marrow findings did not suggest that there was a concomitant idiopathic thrombocytopenic purpura and there was no drug history; it may well have been a secondary hypersplenic effect.

Our patients fall into that category of hereditary nonspherocytic haemolytic anaemia known as Heinz-body anaemia, and, as is characteristic of this disease, the inclusion bodies are demonstrable only after splenectomy. Thus of the 10 affected individuals we examined, only the propositus and her father (C.R. and S.H.), both of whom have had splenectomy, show red-cell 
TABle IV.-Previous Reports of Congenital and Familial Heinz-body Anaemia

\begin{tabular}{|c|c|c|c|c|c|c|c|c|}
\hline Reference & & & No. of Cases & Splenectomy & Familial & Abnormal $\mathrm{Hb}$ & $\begin{array}{l}\text { Inclusions in } \\
\text { Romanovsky- } \\
\text { Stained Films } \\
\text { After } \\
\text { Splenectomy }\end{array}$ & Urine Pigment \\
\hline $\begin{array}{l}\text { Cathie (1952) . } \\
\text { Lange and Akeroyd (1958) }\end{array}$ & $\because$. & 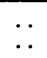 & $\begin{array}{l}1 \\
1\end{array}$ & $\begin{array}{l}\text { Yes } \\
\text { Yes }\end{array}$ & $\begin{array}{l}\text { No } \\
\text { No }\end{array}$ & $\begin{array}{l}\text { No studies } \\
\text { No }\end{array}$ & $\begin{array}{l}\text { Not stated } \\
\text { Yes }\end{array}$ & $\begin{array}{l}\text { "Dark" } \\
\text { Bilifuscin, }\end{array}$ \\
\hline Sohmid et al. (1959) .. & .. & .. & 2 & Yes & Pather and son affected. & Possibly both showed raised $\mathrm{HbA}_{2}$ & Yes & Bilifuscins \\
\hline $\begin{array}{ll}\text { Scott et al. }(1960) & \ldots \\
\text { Worms et al. }(1961) & \ldots\end{array}$ & . & $\because$. & $\begin{array}{l}1 \\
1\end{array}$ & $\begin{array}{l}\text { Yes } \\
\text { Yes }\end{array}$ & $\begin{array}{l}\text { No } \\
\text { Probable }\end{array}$ & $\begin{array}{l}\text { Yes } \\
\text { No }\end{array}$ & $\begin{array}{l}\text { Yes } \\
\text { No }\end{array}$ & $\begin{array}{l}\text { Mesobilifuscin } \\
\text { Mesobilifuscin, }\end{array}$ \\
\hline $\begin{array}{ll}\text { Shibata et al.(1963) } & \ldots \\
\text { Dacie et al. (1964) } & \ldots \\
\text { Present family .. } & \ldots\end{array}$ & $\because$ & $\begin{array}{l}\because \\
\because\end{array}$ & $\begin{array}{r}1 \\
5 \\
10\end{array}$ & $\begin{array}{l}\text { Yes } \\
3 \text { No. } 2 \text { Yes } \\
2 \text { Yes. } 8 \text { No. }\end{array}$ & $\begin{array}{l}\text { No } \\
\text { Yes } \\
\text { Yes }\end{array}$ & $\begin{array}{l}\text { Yes } \\
\text { Yes } \\
\text { Yes }\end{array}$ & $\begin{array}{l}\text { Yes } \\
\text { Yes } \\
\text { No }\end{array}$ & $\begin{array}{l}\text { Urobilinogen } \\
\text { Not studied } \\
\text { Mesobilifuscin }\end{array}$ \\
\hline
\end{tabular}

inclusion bodies, and then only after supravital staining. There appear to be only two accounts in the literature (Mozziconacci, Attal, Pham-Huu-Trung, Malassenet, and Bessis, 1961 ; Dacie et al., 1964) of the haematological investigation of patients who have not had splenectomy. The present report furnishes details an eight unsplenectomized individuals who have this disorder. Apart from the presence of the specific abnormal haemoglobin fraction which one may assume will always be associated with the appearance of Heinz bodies after splenectomy, there is no feature of the blood film or in the general haematological findings which would permit recognition of the probable existence of this form of anaemia prior to splenectomy. In particular, punctate basophilia noted by Dacie et al. (1964) was not a feature. Indeed, the pre-splenectomy blood films, apart from slight anisopoikilocytosis and polychromasia, were unremarkable.

After splenectomy the red-cell inclusions were readily demonstrated. In our cases supravital staining was necessary but in some of those of other authors (see Table IV) the bodies have been visible in Romanowsky-stained films.

Of the further investigations which might be of taxonomic value, heat-precipitability of the haemoglobin, a striking characteristic of Dacie's cases, was clearly demonstrable and would seem likely to prove of value in the diagnosis of familial Heinz-body anaemia before splenectomy. Excessive liability to methaemoglobin production on incubation was also a feature and the incubated blood showed Heinz body formation as Dacie et al. (1964) also observed. Hb Köln shows a greater liability to Heinz-body formation on incubation than does the abnormal haemoglobin present in the cases of Dacie et al. (1964) and is clearly of a different nature in that the "fingerprint" in the report by Dacie is stated to be normal. It is of interest that $\mathrm{Hb}$ Zurich, which appears to undergo degradation readily with the formation of Heinz bodies when sulphonamides are ingested, also shows this excessive liability to form methaemoglobin. The abnormality responsible for $\mathrm{Hb}$ Köln lies in a "core" peptide as in $\mathrm{Hb}$ Zurich and the $M$ haemoglobins also ; these peptides are adjacent to the haem "plate" in the haemoglobin molecule, and this position presumably determines the instability and excessive liability to methaemoglobin production shown by an abnormal haemoglobin of this form. While this development of methaemoglobin on incubation may therefore prove a useful feature in the characterization of "new" haemoglobins by indicating the likelihood of an abnormality in the "core," the concomitant appearance of Heinz bodies within the cells may be found to be an even simpler indication of the presence of a "core" type abnormal haemoglobin, and so may prove useful in the diagnosis of hereditary Heinz-body aneemia ; but further observations on other families will be required to assess this.

\section{Summary}

An abnormal haemoglobin ( $\mathrm{Hb}$ Köln) has been observed in 10 members of a Glasgow family of remote German ancestry. Possession of this haemoglobin variant results in a form of hereditary Heinz-body anaemia and thrombocytopenia.
The clinical and laboratory findings in this family are presented and the characterization of the haemoglobin variant is described. The relationship of this variant to the haemolytic anaemia, Heinz-body formation, and thrombocytopenia is discussed.

We are indebted to Professor E. M. McGirr and Drs. R. Cordiner, R. L. Richards, R. A. Shanks, and Ian Wang for permission to publish details of cases investigated under their care ; to Drs. G. A. McDonald and J. H. Dagg for chromium studies ; to Dr. J. C. Eaton for quantitation of the methaemoglobin investigations; and to Drs. D. C. Nicholson and A. Goldberg for the urinary pigment determinations. Professor T. A. J. Prankerd kindly. performed erythrocyte enzyme estimations. Mrs. Glenna Knight and Miss P. A. M. Kynoch have rendered valuable technical assistance.

\section{REFERENCES}

Bachmann, F. (1962). In Haemoglobin-Colloquium, Wten 31 August 1961, edited by H. Lehmann and K. Betke, p. 52. Thiem, Stuttgart. Baglioni, C. (1961). Biochem. biophys. Acta. (Amst.), 48, 392.

Barkan, P., Stevenson, M. E., Pinker, G., Dance, N., and Shooter, E. M. (1964). Brit. 7. Haemat. 10, 437.

Beutler, E. (1959). Blood, 14, 103.

Cathie, I. A. B. (1952). Gt Ormond Str. 7., 3, 43

Cradock-Watson, J. E., Fenton, J. B. C., and Lehmann, H. (1959). F. clin. Path., 12, 372

Dacie, J. V. (1960). The Haemolytic Anaemias, 2nd ed., pt. 1, p. 180. Churchill, London.

Grimes, A. J., Meisler, A., Steingold, L., Hemsted, E. H., Beaven, G. H., and White, J. C. (1964). Brit. F. Haemat., 10, 388.

and Lewis, S. M. (1963). Practical Haematology, 3rd ed. Churchill, London.

Doxiadis, S. A., Fessas, P., Valaes, T., and Mastrokalos, N. (1961). Lancet, 1, 297.

Fessas, Ph., Stamatoyannopoulos, G., and Karaklis, A. (1962). Blood, $19,1$.

Frick, P. G., Hitzig, W. H., and Betke, K. (1962). Ibid., 20, 261.

Grimes, A.'J., Meisler, A., and Dacie, J. V. (1964). Brit. 尹. Haemat., 10, 281.

Huehns, E. R., Shooter, E. M., and Beaven, G. H. (1962). F. molec. Biol., 4, 323 .

Huisman, T. H. J. (1963). In Advances in Clinical Chemistry, vol. 5 , p. 281, edited by H. Sobotka and C. P. Stewart. Academic Press, London.

Hutchison, H. E., Jackson, J. M., and Cassidy, P. (1962). Lancet, 2 1022 .

Pinkerton, P. H., Aiton, M., and Cassidy, P. (1963). Scot. med. F., 8, 149 .

Ingram, V. M. (1958). Biochem. biophys. Acta. (Amst.), 28, 539.

Itano, H. A., and Robinson, B. (1959). Nature (Lond.), 184, 1468.

Josephson, A. M., Weinstein, H. G. Yakulis, V. J., Singer, L., and

Heller, P. (1962). 7. Lab. clin. Med..,59, 918 ., Sin
Lange, R. D., and Akeroyd, J. H. (1958), Blood, 13, 950.

Lelong, M., Fleury, J., Alagille, D., Malassenet, R., Lortholary, P., and Para, M. (1961). "Nouv. Rev. franc. Hémat., 1, 819.

Mollison, P. L., and Veall, N. (1955). Brit. F. Haemat., 1, 62.

Mozziconacci, P., Attal, C., Pham-Huu-Trung, Malassenet, R., and Bessis, M. (1961). Nouv. Rev. franç. Hémat., 1, 832.

Poulik, M. D. (1957). Nature (Lond.), 180, 1477.

Pribilla, W. (1962). In Haemoglobin-Colloquium, Wien, 31 August 1961 , p. 73, edited by H. Lehmann and K. Betke. Thiem, Stuttgart. Robinson, A. R., Robson, M., Harrison, A. P., and Zuelzer, W. W. (1957). भ. Lab. clin. Med., 50, 745.

Schmid, R., Brecher, G., and Clemens, T. (1959). Blood, 14, 991.

Scott, J. L., Haut, A., Cartwright, G. E., Wintrobe, M. M. (1960). Ibid., 16, 1239 .

Selwyn, J. G., and Dacie, J. V. (1954). Ibid., 9, 414.

Shibata, S., Iuchi, I., Miyaji, T., Ueda, S., and Takeda, I. (1963). Acto haemat. jap., 26, 164.

Singer, K., Chernoff, A. I., and Singer, L. (1951). Blood, 6, 413

Singer, K., Chernoff, A. I., and Singer, L. (1951). Blood,

Went, L. N., and Maclver, J. E. (1961). Ibid., 17, 166. (1961). Nouv. Rev. franç. Hemat., 1, 805 . 